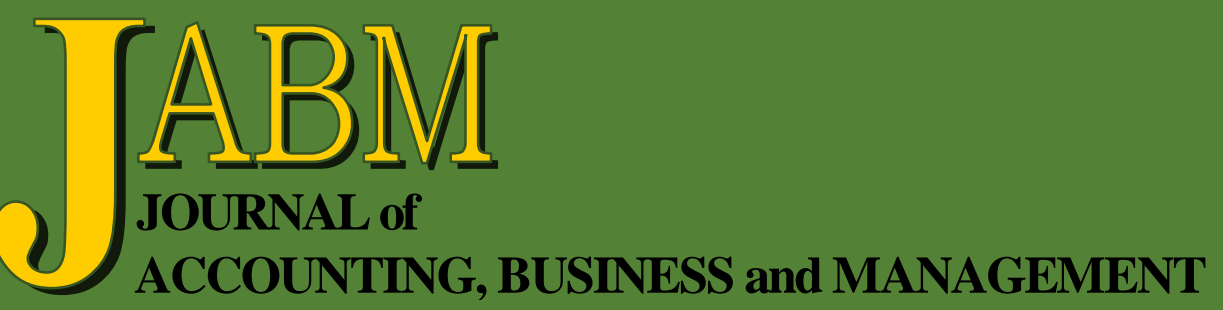

An Analysis of Management Accounting System Development from the Structuration Theory Viewpoint

Anthony Moung Yin Chan, Paul Lo and Kong Ng

Impact of Total Asset Turnover Ratios on Equity Returns: Dynamic Panel Data Analyses

Jeanne-Claire Patin, Matiur Rahman and Muhammad Mustafa

The Impact of Audit Committees on US Nonprofit Organizations'

Governance

Husam Abu-Khadra

Implicit Taxes Amid Race to the Bottom in a Global Tax Game

Igor Semenenko, Junwook Yoo and Parporn Akathaporn

The Adoption of Financial Accounting Standards for Small Medium Enterprises by Muslim Entrepreneurs

Muslichah, Sunarto, Anang Amir Kusnanto, Sri Indrawati and Hariyanto

The Impact of E-Procurement Systems in the Biomedical Industry

A. Seetharaman, Nitin Patwa, Simon Lai Koek Wai and Ahammed Shamir

After-Tax Discounting: A Research Edge

Hongtao Guo

Rules-Based Accounting Standards and SEC Enforcement

Devon Baranek 
Journal of Accounting, Business and Management vol. 27 no. 1 (2020) 30-41

\title{
The Impact of Audit Committees on US Nonprofit Organizations' Governance
}

\author{
Husam Abu-Khadra*
}

\begin{abstract}
All public companies in the United States are required by the securities and exchange commission (SEC) to have an audit committee. Such enforcement can be attributed to high-profile corporate failures and their connections to nonexistence, ineffective or weak audit committees and governance. Despite the efforts to establish a similar argument and enforcement structure for the nonprofit sector, the internal revenue service (IRS) has not pursued legislation, and no empirical evidence has been established to support any public policy changes. This paper contributes to the literature in this field by being the first study to examine 124,980 nonprofit organizations during the period of 2010 to 2015 to test the association between governance in nonprofit organizations and audit committees. We included fifteen measures from these organizations' IRS Form 990 filings to formulate the study variables. We found significant evidence that the existence of audit committees improves the governance scores of nonprofit organizations. Our study findings have significant implications for nonprofit executives, policy makers and any other interested parties; these findings act as preliminary evidence to support more proactive policies regarding mandatory audit committees for nonprofit organizations.
\end{abstract}

Keywords: audit committee, nonprofit, governance, IRS Form 990, fraud, internal control.

\section{INTRODUCTION}

During the last two decades, for-profit companies have witnessed a renewed focus on governance motivated mainly by a number of high-profile corporate failures, many of which were subsequently tied to either weak or ineffective governance structures (Ghafran \& O'Sullivan, 2013). As a result, several recommendations were formulated to fix this problem, with an emphasis on audit committees being a powerful source of improvement in corporate governance (Cadbury, 1992; Turley \& Zaman, 2004). This argument was supported by the literature that examined the audit committee effect on governance (Sommer, 1991; Lee, 2001).

Despite the importance of audit committees, and unlike for-profit organizations, nonprofit organizations are not required to maintain audit committees (National Council of Nonprofits, 2018); the internal revenue service (IRS), in their redesigned 2008 tax form, the IRS Form 990 entitled (return of organization exempt form income tax), first required that nonprofit organizations disclose whether the organization had an audit committee or not. However, the IRS does not mandate that nonprofit organizations have audit committees, leaving in place significant variations in the deployment of such an important committee and creating a trickle-down effect on governance practices.

\footnotetext{
* Associate Professor of Accounting. Heller College of Business, Roosevelt University. 425 S. Wabash Ave., Chicago, Room 1112, 1400 N. Roosevelt Blvd, Schaumburg, IL, Room 130. Phone: 312-341-6775. E-mail: habukhadra@roosevelt.edu.
} 
Unfortunately, the IRS's efforts did not help and contributed to a catastrophic growth in fraud and fund embezzlement rates (Abu-Khadra et al., 2017). Furthermore, nonprofit organizations in the United States have been subject to media and public enquiries (McDonnell \& Rutherford, 2018); in October 2013, a report published by the Washington Post revealed that more than one thousand nonprofit organizations had reported losses totaling more than $\$ 250$ million from fraud, embezzlement, theft or other improper uses of funds (The Washington Post, 2013). Despite this report, not much action was taken to solve this issue; as a result, more and more significant fraud cases have occurred over the years. According to the 2018 association of certified fraud examiners' (ACFE's) Report to the Nation, nonprofit entities made up 9\% of the reported and analyzed fraud cases. It was also reported that such organizations suffered a median loss of $\$ 75 \mathrm{~K}$. This loss may not seem significant; however, for many nonprofit entities, financial resources are extremely limited and a loss of $\$ 75 \mathrm{~K}$ can be particularly devastating (ACFE, 2018).

In this study, we aim to provide initial evidence to help solve this problem by examining the impact of the existence of an audit committee on the governance practices of a nonprofit organization, which could have significant implications for nonprofit executives, policy makers and other interested parties. The outcome of this study will act as preliminary evidence to support more proactive policy changes regarding the application of audit committees to nonprofit organizations; it will also contribute to the current debate regarding nonprofit organization regulations and public policy. To the best of our knowledge, this paper is the first to provide empirical evidence regarding the impact of the existence of an audit committee on the governance of a nonprofit organization.

To test our hypothesis that having an audit committee increases the governance strength score of a nonprofit organization, we examined all the files from the annual extracts of tax-exempt organizations' Form 990 reporting. Our data was extracted directly from the IRS sample of income (SOI) database for the years 2010-2015. The dataset contained information on 124,980 US nonprofit organizations. Despite the availability of older datasets, we excluded data files from the financial crisis, i.e., 2007-2009, which was important in terms of minimizing the impacts of any undesired significant external environmental factors, such as the economic recession, on the outcomes of this study. We used 15 different questions from Form 990 in our study, whereby 14 questions contributed to the governance score used as the dependent variable, while one question provided information for the independent variable audit committee. Due to the score nature of the dependent variable in our study, we used Poisson logistic regression. Furthermore, we confirmed our results by utilizing a twostep data transformation and liner regression that fits the transformed data.

Our results indicate that audit committee existence correlates positively with stronger governance in nonprofit organizations. The IRS approach provides an interesting contrast to governance reforms for publicly traded companies; the IRS has taken a disclosure route as opposed to the obligatory adoption approach adopted by the securities and exchange commission (SEC) (Harris et al., 2015).

The next section discusses the study background and presents the study hypothesis. The third section describes the data used and conveys its findings. Lastly, the fourth and fifth sections conclude with the study's outcomes, discussion and any potential implications. 


\section{BACKGROUND AND HYPOTHESIS DEVELOPMENT}

There is no uniform definition as to what corporate governance entails, but it widely accepted that it is a system that contains a set of rules, controls, policies and resolutions regarding a company's practices that aids management in directing and controlling the company in the best interests of its shareholders and other stakeholders by establishing better financial reporting and more transparency (Shleifer \& Vishny, 1997; Puri et al., 2010). It is also widely accepted that the audit committee has always played a critical role in for-profit corporate governance, and it is perceived of as one of the main approaches to strengthen corporate governance (Saibaba \& Ansari, 2012; Lee, 2015; and Klemash \& Lee, 2018). Nevertheless, in the US, the use of audit committees was not enforced until the widespread publicity surrounding the failure of Enron, and later WorldCom, lead to the enactment of the Sarbanes-Oxley Act (SOX) of 2002 (Narayanaswamy et al., 2015). This legislation is seen as a reactive move by lawmakers, one that would not have taken place if there had not been huge losses and public outcry.

On the other hand, nonprofit organization, regardless of the frequent failures/fraud cases reported, did not receive similar treatment. At the federal level, the IRS has taken a disclosure approach as opposed to the obligatory adoption approach used by the SEC. Since the 2008 redesign of the IRS Form 990, nonprofit organizations have been required to report on several aspects of their organizational governance structures. Such disclosures take place in Form 990, part VI, section A, entitled "governance, management and disclosure." In this section, the IRS requires organizations to answer a questionnaire about their governance practices but does not mandate any specific governance policies. The new IRS Form 990 governance reporting requirement came as a response to the panel on the nonprofit sector 2007 report (The Panel on the Nonprofit Sector, 2007). This report attempted to achieve a balance between what nonprofits must do and what it is recommended that they do. Despite public criticism, many find this report a positive beginning step in the push for stronger governance in nonprofit organizations (Lampkin, 2008).

Based on the discussion above, we constructed our hypothesis concerning the argument that the nonexistence of audit committee results in weaker governance scores for nonprofit organizations. In order to examine the association between governance and audit committees in nonprofit organizations, we will use the governance and audit committee questions on the IRS Form 990 mentioned above. Our hypothesis assumes that the existence of audit committees will improve governance practices; an audit committee provides oversight for the audit process as well as the organization's system of internal controls and compliance with laws and regulations. The study's hypothesis reads:

$\mathbf{H}_{1}$ : all else being equal, audit committees do influence governance practices in nonprofit organizations.

In the following paragraphs we discuss several of the governance questions that were included in section VI of the IRS Form 990. The IRS dedicated several governance questions to management practices, and two of these questions asked about management decision delegation and management disclosure of any family relationships. Delegation relationships are found in both the for-profit and nonprofit setting since companies are always concerned about controlling the costs arising from opportunistic behavior and goal conflicts (Krzeminska \& Zeyen, 2016). As a result, the IRS considered management delegation to be an important aspect since it can give a 
rise to conflicts among the actors involved and may lead to higher risk. When it comes to family ties, it is important to ask any officer, director, trustee or key employee that have family or business relationships to disclose such relationships. Overlooking this aspect may present a potential conflict of interest that is never addressed or dealt with. The board is responsible for setting the tone at the top and requiring such disclosures. To do otherwise can lead to fraud and corruption that is not readily seen by various stakeholders.

The IRS, in its publication, paid a lot of attention to conflict policies. It considered conflict of interest policies to be effective tools in terms of protecting organizations' finances and reputations. These policies also provide protection for the beneficiaries of organizations' missions by making sure that all resources are clearly designated for the purposes for which they were intended (Fox, 2008). The IRS created three questions in this field: one question dealt with the existence of a conflict of interest policy, while the second addressed whether disclosure took place, and the third question asked whether such a policy was enforced. These questions can be used to represent the "pressure" and "opportunity" elements of the fraud triangle (or diamond) (Cressey, 1950; Albrecht et al., 2016). Not having an enforced conflict-of-interest policy can give rise to fraud by not identifying individuals at risk and, consequently, providing an actual or perceived opportunity to perpetrate fraud. Todd (2016) indicates that when it comes to corruption, there is almost always a conflict of interest in the common denominator. It is important to keep in mind that any policy without active enforcement and monitoring is not an effective policy and has no teeth. It will not be taken seriously by those whom the policy is meant to deter and will render such policies useless (DC Bar Pro Bono, 2015).

Finally, according to the ACFE, tips from whistleblowers are the most common and effective fraud detection method; $40 \%$ of occupational fraud is detected initially through tips (ACFE, 2018). Despite the effectiveness of tips, whistleblowers often fear being identified or retaliated against, which is why it is important to have a whistleblower policy that enable these individuals to make reports anonymously whenever such a practice is legally permissible. All organizations, including nonprofits, should consider implementing whistleblowing provisions (Eaton \& Akers, 2007). This aspect was addressed in one question on Form 990.

\section{DATA AND MODEL}

In this study, we used the Statistics of Income (SOI) microdata file dataset published by the IRS. Microdata files are individual, organizational-level data that are made available for research purposes. At the time this study was conducted, microdata files were available for the years 1985-2015. To avoid any undesired bias in the data as a result of uncontrolled external environmental variables, such as the 2007-2009 recession that the United States suffered from, we used the data for the years 20102015, as shown in Table 1.

Insert Table 1 here.

The data for the dependent variable governance was collected from the answers provided in the IRS Form 990, part VI questionnaire. In part VI of Form 990, entitled "governance, management, and disclosure," the IRS asks several questions that can be attributed to governance. At this stage, based on the literature in the field, we selected 14 questions to represent a composite governance dependent variable. Composite variables are aggregations of measurable variables that aim to quantify underlying concepts that are not observable directly (Becker et al., 2017). To calculate 
the governance composite variable, we first transformed all the negative question answers in such a manner as to make sure that all questions were in the same direction. Then we used a meaningful grouping that was highlighted by Song et al. (2013) to create one governance score for each case in our dataset. Here, meaningful grouping refers to the non-statistical combination of selected original variables based on the interpretation of the variables' values or scores, under the guidance of the literature in the field. The questions that were selected to represent governance variable are listed in Table (2). All the selected questions in this part produced dichotomous raw data, i.e., the respondents were asked to answer either "yes" or "no".

Table 1

SOI Database Details

\begin{tabular}{cc}
\hline Year & IRS SOI Dataset Size \\
\hline 2010 & 19466 \\
2011 & 19809 \\
2012 & 20497 \\
2013 & 21261 \\
2014 & 21790 \\
2015 & 22160 \\
\hline Total & $\mathbf{1 2 4 9 8 0}$ \\
\hline
\end{tabular}

Table 2

Governance Variable Form 990 Questions

Question

Number on

Form 990,

Part VI

2* Did any officer, director, trustee, or key employee have a family elation-ship or a business relationship with any other officer, director, trustee, or key employee?

3* Did the organization delegate control over management duties customarily performed by or under the direct supervision of officers, directors or trustees, or key employees to a management company or other person?

8a Did the organization contemporaneously document the meetings held or written actions undertaken during the year by the governing body?

8b Did the organization contemporaneously document the meetings held or written actions undertaken during the year by each committee with authority to act on behalf of the governing body?

9* Is there any officer, director, trustee, or key employee listed in Part VII, Section A, who cannot be reached at the organization's mailing address?

11a Has the organization provided a complete copy of this Form 990 to all members of its governing body before filing the form?

12a Did the organization have a written conflict of interest policy?

12b Were officers, directors or trustees, and key employees required to disclose annually interests that could give rise to conflicts?

12c Did the organization regularly and consistently monitor and enforce compliance with the policy?

13 Did the organization have a written whistleblower policy?

14 Did the organization have a written document retention and destruction policy? 
To be continued Table 2 .

15a Did the process for determining compensation of (the organization's CEO, executive director, or top management official) include a review and approval by independent persons, comparability data, and contemporaneous substantiation of the deliberation and decision?

15b Did the process for determining compensation of (other officers or key employees of the organization.) include a review and approval by independent persons, comparability data, and contemporaneous substantiation of the deliberation and decision?

16b Did the organization follow a written policy or procedure requiring the organization to evaluate its participation in joint venture arrangements under applicable federal tax law, and take steps to safeguard the organization's exempt status with respect to such arrangements?

\section{* Represent negative questions.}

To identify the independent variable, we reviewed form 990, part XII, which is entitled "financial statement and reporting." In this part, we identified audit committee as the independent variable and measured it using the following question listed in Table 3. The audit committee question in this part produced dichotomous data, as the respondents were asked to answer either "yes" or "no".

Table 3

Audit Committee Question in Form 990

\section{Question Number on Form 990, Part XII \\ Question}

2c

Does the organization have a committee that assumes responsibility for oversight of the audit, review, or compilation of its financial statements and selection of an independent accountant?

To establish the face validity of the Form 990 part VI and XII questionnaires, we relied on the fact that the form was formed based on expert review and feedback; the revised form was created by the IRS in 2008 as response to the panel on the nonprofit sector 2007 report (The Panel on the Nonprofit Sector, 2007). This panel represented a group of foundation and nonprofit officials convened by the Independent Sector at the request of Congress to improve accountability and ethical practice in charitable organizations.

Once we calculated the composite score for the governance variable, we moved forward with conducting a reliability analysis, which allowed us to check how the items worked together to assess the variable. In other words, we used Cronbach's alpha to evaluate the reliability of the items comprising the composite score. This statistic allows one to make a statement regarding the acceptability of using a particular combination of items to represent your variable. Cronbach's alphas of at least 0.7 indicate that the combination of items has acceptable reliability (George \& Mallery, 2016).

To test the study hypothesis, we chose Poisson regression as a parametric procedure despite the data exhibiting a skewed distribution. Although true normality is considered to be a myth (Elliott \& Woodward, 2007), we only need to consider the normality of data if we are using a small sample size. With a large enough sample size, the violation of the normality assumption for the data should not cause major problems (Pallant, 2007), implying that we can use parametric procedures even when the data are not normally distributed if we have sample consisting of hundreds of observations, as in our study (Ghasemi \& Zahediasl, 2012). Poisson regression is a type of general linear model (GLM) that is used to predict a dependent variable that consists 
of "count data" with one or more independent variables. It also assumes that each subject is observed for the same length of time, and the dependent variable is not overdispersed and does not have an excessive number of zeros (UCLA Stats, 2016).

To confirm the Poisson regression results, we also used multiple regression after conducting a two-step data transformation that was suggested by Templeton (2011). This transformation is done so that the dependent variable data is presented in a continuous format with a mean value of 0 and standard deviation of 1 , with these mean and standard deviation values matching those of a Gaussian distribution. To execute this transformation, we: (i) created a new variable using the fractional rank function in the SPSS rank cases menu, and (ii) transformed the newly created variable using the IDF.NORMAL function in the SPSS compute variable menu. All the data analyses were performed using SPSS 25.

\section{RESULTS}

To measure the internal consistency of the questionnaire's stability across components, we relied on Cronbach's alpha. The alpha coefficient for the 14 items was 0.795, suggesting that such questions have relatively acceptable internal consistency. A reliability coefficient of .70 or higher is considered acceptable in most social science research situations (UCLA Stats, 2019). Furthermore, we ran a Cronbach's alpha test with each item deleted in turn, giving us the opportunity to boost the measure score to 0.823 if we deleted the question related to executive relationships. We elected to keep all the questions in the composite score given the initial alpha score was acceptable and to avoid eliminating an important question for the sake of a higher Cronbach's alpha score.

As shown in Table 4, the descriptive statistics for the governance score questions show that most nonprofit organizations adopted most of the measured governance aspects. An exception was the adoption of governance policies surrounding the process of determining the compensation levels for organizations' key employees; roughly $45 \%$ of the organizations did adopt such a policy. Furthermore, almost $94 \%$ of studied organizations did not have any written policy or procedure requiring the organization to evaluate its participation in joint venture arrangements under applicable federal tax law and take steps to safeguard the organization's exempt status with respect to such arrangements.

\section{Table 4}

Frequencies for the Form 990 Governance Questions

\begin{tabular}{|c|c|c|c|c|}
\hline $\begin{array}{l}\text { Measure } \\
\text { Code }\end{array}$ & $\begin{array}{c}\text { Description of } \\
\text { Question Content }\end{array}$ & $\begin{array}{l}\text { Form } 990 \\
\text { Question } \\
\text { Reference }\end{array}$ & $\begin{array}{c}\text { Frequency/ } \\
\text { Percentage } \\
\text { Value }=0^{*}\end{array}$ & $\begin{array}{c}\text { Frequency / } \\
\text { Percentage } \\
\text { Value }=1 \\
\end{array}$ \\
\hline $\begin{array}{l}\text { Management } \\
\text { compensation }\end{array}$ & $\begin{array}{l}\text { The process of determining } \\
\text { the organization's CEO } \\
\text { compensation was reviewed } \\
\text { by independent persons. }\end{array}$ & $\begin{array}{c}\text { Part VI, } \\
\text { question 15a }\end{array}$ & $\begin{array}{l}43498 \\
34.8 \%\end{array}$ & $\begin{array}{l}81483 \\
65.2 \%\end{array}$ \\
\hline $\begin{array}{l}\text { Key } \\
\text { compensation }\end{array}$ & $\begin{array}{l}\text { The process of determining } \\
\text { the organization's key } \\
\text { employees' compensations } \\
\text { was reviewed by independent } \\
\text { persons. }\end{array}$ & $\begin{array}{c}\text { Part VI, } \\
\text { question 15b }\end{array}$ & $\begin{array}{l}56293 \\
45.0 \%\end{array}$ & $\begin{array}{l}68688 \\
55.0 \%\end{array}$ \\
\hline $\begin{array}{l}\text { Management } \\
\text { delegation }\end{array}$ & $\begin{array}{l}\text { Organization delegates con- } \\
\text { trol of management duties to } \\
\text { a management company or } \\
\text { other person. }\end{array}$ & $\begin{array}{c}\text { Part VI, } \\
\text { question } 3\end{array}$ & $\begin{array}{l}10069 \\
8.1 \%\end{array}$ & $\begin{array}{l}114912 \\
91.9 \%\end{array}$ \\
\hline
\end{tabular}


To be continued Table 4 .

\begin{tabular}{|c|c|c|c|c|}
\hline Relation & $\begin{array}{l}\text { Any officer, director, trustee } \\
\text { or key employee having a } \\
\text { family relation-ship or a } \\
\text { business relationship with } \\
\text { any other officer, director, } \\
\text { trustee or key employee. }\end{array}$ & $\begin{array}{c}\text { Part VI, } \\
\text { question } 2\end{array}$ & $\begin{array}{l}22888 \\
18.3 \%\end{array}$ & $\begin{array}{c}102093 \\
81.7 \%\end{array}$ \\
\hline $\begin{array}{l}\text { Governing } \\
\text { minutes }\end{array}$ & $\begin{array}{l}\text { Organization contemporane- } \\
\text { ously documents the } \\
\text { meetings held or written } \\
\text { actions undertaken during } \\
\text { the year by the governing } \\
\text { body. }\end{array}$ & $\begin{array}{c}\text { Part VI, } \\
\text { question } 8 \mathrm{a}\end{array}$ & $\begin{array}{l}3502 \\
2.8 \%\end{array}$ & $\begin{array}{r}121479 \\
97.2 \%\end{array}$ \\
\hline $\begin{array}{l}\text { Committee } \\
\text { minutes }\end{array}$ & $\begin{array}{l}\text { Organization contemporane- } \\
\text { ously document the meetings } \\
\text { held or written actions } \\
\text { undertaken during the year } \\
\text { by each committee with } \\
\text { authority to act on behalf of } \\
\text { the governing body. }\end{array}$ & $\begin{array}{c}\text { Part VI, } \\
\text { question } 8 \mathrm{~b}\end{array}$ & $\begin{array}{l}13555 \\
10.8 \%\end{array}$ & $\begin{array}{c}111426 \\
89.2 \%\end{array}$ \\
\hline $\begin{array}{l}\text { Conflict } \\
\text { policy }\end{array}$ & $\begin{array}{l}\text { The organization has a } \\
\text { written conflict of interest } \\
\text { policy. }\end{array}$ & $\begin{array}{c}\text { Part VI, } \\
\text { question } 12 \mathrm{a}\end{array}$ & $\begin{array}{l}23504 \\
18.8 \%\end{array}$ & $\begin{array}{l}101477 \\
81.2 \%\end{array}$ \\
\hline $\begin{array}{l}\text { Conflict } \\
\text { disclosure }\end{array}$ & $\begin{array}{l}\text { Officers, directors or trustees } \\
\text { and key employees required } \\
\text { to disclose annually interests } \\
\text { that could give rise to } \\
\text { conflicts. }\end{array}$ & $\begin{array}{c}\text { Part VI, } \\
\text { question } 12 \mathrm{~b}\end{array}$ & $\begin{array}{l}28353 \\
22.7 \%\end{array}$ & $\begin{array}{l}96628 \\
77.3 \%\end{array}$ \\
\hline $\begin{array}{l}\text { Conflict } \\
\text { enforcement }\end{array}$ & $\begin{array}{l}\text { The organization regularly } \\
\text { and consistently monitors } \\
\text { and enforces compliance } \\
\text { with the conflict of interest } \\
\text { policy. }\end{array}$ & $\begin{array}{c}\text { Part VI, } \\
\text { question } 12 \mathrm{c}\end{array}$ & $\begin{array}{l}30053 \\
24.0 \%\end{array}$ & $\begin{array}{l}94928 \\
76.0 \%\end{array}$ \\
\hline $\begin{array}{l}\text { Whistleblower } \\
\text { policy } \\
\text { Document } \\
\text { policy }\end{array}$ & $\begin{array}{l}\text { The organization has a } \\
\text { written whistleblower policy. } \\
\text { The organization has a } \\
\text { written document retention } \\
\text { and destruction policy. }\end{array}$ & $\begin{array}{l}\text { Part VI, } \\
\text { question } 13 \\
\text { Part VI, } \\
\text { question } 14\end{array}$ & $\begin{array}{l}37280 \\
29.8 \% \\
32406 \\
25.9 \%\end{array}$ & $\begin{array}{l}87701 \\
70.2 \% \\
92575 \\
74.1 \%\end{array}$ \\
\hline $\begin{array}{l}\text { Law } \\
\text { compliance }\end{array}$ & $\begin{array}{l}\text { The organization follows a } \\
\text { written policy or procedure } \\
\text { requiring the organization to } \\
\text { evaluate its participation in } \\
\text { joint venture arrangements } \\
\text { under applicable federal tax } \\
\text { law and takes steps to sa- } \\
\text { feguard the organization's } \\
\text { exempt status with respect to } \\
\text { such arrangements. }\end{array}$ & $\begin{array}{c}\text { Part VI, } \\
\text { question 16b }\end{array}$ & $\begin{array}{l}117311 \\
93.9 \%\end{array}$ & $\begin{array}{l}7670 \\
6.1 \%\end{array}$ \\
\hline $\begin{array}{l}\text { Reach } \\
\text { executives }\end{array}$ & $\begin{array}{l}\text { All officers, directors, } \\
\text { trustees or any key em- } \\
\text { ployees who cannot be } \\
\text { reached at the organization's } \\
\text { mailing address. }\end{array}$ & $\begin{array}{c}\text { Part VI, } \\
\text { question } 9\end{array}$ & $\begin{array}{l}9883 \\
7.9 \%\end{array}$ & $\begin{array}{c}115098 \\
92.1 \%\end{array}$ \\
\hline $\begin{array}{l}\text { Form } \\
\text { governing }\end{array}$ & $\begin{array}{l}\text { The organization provided a } \\
\text { complete copy of this Form } \\
990 \text { to all members of its } \\
\text { governing body before filing } \\
\text { the form. }\end{array}$ & $\begin{array}{c}\text { Part VI, } \\
\text { question } 11 \mathrm{a}\end{array}$ & $\begin{array}{l}28871 \\
23.1 \%\end{array}$ & $\begin{array}{l}96110 \\
76.9 \%\end{array}$ \\
\hline
\end{tabular}

- Zero being no and 1 being yes 
After transforming the individual governance questions into one composite score, we ran the Poisson regression to test the causality relationship between the governance composite score and the existence of an audit committee. In SPSS, the predictor variable was included as a Factor and not as Covariate due to its nominal nature. As shown in Table 5, the omnibus test results were significant, which means that our model showed significant improvement over the intercept-only model.

Table 5

Model Omnibus Test Results

\begin{tabular}{ccc}
\hline Likelihood Ratio Chi-Square & df & Sig. \\
\hline 25302.81 & 1 & 0 \\
\hline
\end{tabular}

Note:

Dependent Variable: Governance_score_14

Model: (Intercept), audit committee.

a. Compares the fitted model against the intercept-only model.

In Table 6, the Exp. (B) value in the Poisson regression outcome is the exponentiated value of the coefficient $\mathrm{B}$ and is an odds ratio for $\mathrm{B}$. When the audit committee was not present, the Exp. (B) value was equal to 0.690 with a p-value of 0.000 , which indicates that the governance score was affected negatively by the absence of an audit committee. In other words, when audit committees are not present, we can expect a reduction in the governance score equal to $37.1 \%$. Consequently, we reject the null hypothesis and conclude that the lack of an audit committee has a significant negative influence on an organization's governance score.

Table 6.

Poisson Regression Analysis Results

\begin{tabular}{|c|c|c|c|c|c|c|c|c|}
\hline \multirow{2}{*}{ Parameter } & \multirow[t]{2}{*}{ B } & \multirow{2}{*}{$\begin{array}{l}\text { Std. } \\
\text { Error }\end{array}$} & \multicolumn{2}{|c|}{$\begin{array}{l}95 \% \text { Wald } \\
\text { Confidence } \\
\text { Interval }\end{array}$} & \multicolumn{3}{|c|}{$\begin{array}{c}\text { Hypothesis } \\
\text { Test }\end{array}$} & \multirow{2}{*}{$\begin{array}{l}\text { Exp. } \\
\text { (B) }\end{array}$} \\
\hline & & & Lower & Upper & $\begin{array}{l}\text { Wald Chi- } \\
\text { Square }\end{array}$ & df & Sig. & \\
\hline (Intercept) & 2.403 & .0010 & 2.401 & 2.405 & 6305681.22 & 1 & .000 & 11.060 \\
\hline$[$ audit_committee $=0]$ & -.371 & .0024 & -0.375 & -0.366 & 23271.944 & 1 & .000 & 0.690 \\
\hline [audit_committee=1] & $0^{a}$ & & & & & & & 1 \\
\hline (Scale) & $1^{\mathrm{b}}$ & & & & & & & \\
\hline
\end{tabular}

Note:

Dependent Variable: Governance_score_14

Model: (Intercept), audit committee.

a. Set to zero because this parameter is redundant.

b. Fixed at the displayed value.

To verify the Poisson regression results, we used linear regression after transforming the data using Templeton's (2011) data transformation methodology. The transformation methodology enabled us to transform the score nature of the dependent variable to a data format that is more suitable for linear regression. The transformed data showed residual plot charts and scatterplot results consistent with the liner regression assumptions. Further, the linear regression results provided an $\mathrm{R}$ value of 0.458 and adjusted $\mathrm{R}$-square value of 0.21 . It is important to keep in mind that the R-square value should be examined within the context of a study, and that, in some cases, explaining $10 \%$ of the variability in the dependent variable can be considered a good outcome (Nau, 2018). In other words, having an adjusted R-square value of 0.21 is considered a good outcome considering that the existence of an audit 
committee alone explained $21 \%$ of the variability in the governance score. Such an outcome also supports our previous decision regarding the study hypothesis.

\section{DISCUSSION AND CONCLUSION}

Audit committee is a key component of corporate governance and play critical role to strengthen it. As defined Sarbanes-Oxley Act of 2002, section 2, audit committees oversee the accounting and financial reporting process of the issuer and audits of the financial statements of the issuer (Beasley et al., 2010). Nevertheless, in the US, the use of audit committees is not enforced in nonprofit organization. At the federal level, the IRS has taken a disclosure approach in Form 990 as opposed to the obligatory adoption approach used by the SEC for public companies. Critics argued that a disclosure approach is not enough, but no evidence was provided to support mandating audit committees for nonprofit organizations. This paper provides such evidence by analyzing governance in nonprofit organizations and how it is influenced by the existence of audit committees. The measured governance factors and audit committee information were drawn from the IRS Form 990. To the best of our knowledge, this study is the first to provide empirical evidence of the impact of the existence of an audit committee on governance in nonprofit organizations.

The study results indicated that audit committee existence promotes stronger governance in nonprofit organizations. Such an outcome provides evidence that supports the widely accepted theory and for-profit empirical evidence that audit committees affect governance practices (Sommer, 1991; Lee, 2001; Saibaba \& Ansari, 2012; Lee, 2015; and Klemash \& Lee, 2018). Furthermore, Nonprofit organizations showed high adoption rates to policies overseeing the process of taking meetings' minutes, conflict of interest, accessibility to executives. On other hand, significant number of nonprofit organizations don't have written policy or procedure to ensure that organization safeguard their nonprofit exempt status. Such disparity in policies adoption should be given more attention by nonprofit organizations management; gaps in the governance system could represent an invitation to fraud, waste of resources and/or asset misappropriation.

Despite this study providing supporting evidence that audit committees are an important factor in improving corporate governance, more research is needed in this field and to expand on the findings of this study; it is important to study more variables that affect the performance of audit committees in nonprofit organizations, including, but not limited to, the expertise of committee members, committee size and the frequency of committee meetings. We should note that our analysis relies on Form 990 reporting, which created some challenges since the IRS only requires organizations to report on specific aspects related to corporate governance and audit committees. Consequently, no data was available for other factors related to these areas. Finally, our study results should not be considered definitive evidence, as any evidence regarding governance enforcement in the nonprofit sector must receive careful consideration in terms of cost-benefit analyses and the unique nature of nonprofit organizations.

\section{REFERENCES}

Abu-Khadra, H., Stinnette, U., \& Friel, T. (2017). Fraud in nonprofit education organization. Paper presented at Proceedings of North American Accounting Society Conference. Chicago, MBAA International Conference. 
ACFE. (2018). Report to the nations: 2018 global study on occupational fraud and abuse. Retrieved April 20, 2019 from https://www.acfe.com/uploadedFiles/ ACFE_Website/Content/rttn/2018/RTTN-Government-Edition.pdf.

Albrecht, W. S., Albrecht, C. I., Albrecht, C. C., \& Zimbelman, M. F. (2016). Fraud examination ( $5^{\text {th }}$ ed.). Boston, MA, USA: Cengage Learning.

Beasley, M. S., Carcello, J. V., Hermanson, D. R., \& Neal, T. L. (2010). The audit committee oversight process. Contemporary Accounting Research, 26(1), 65-122.

Becker, W., Saisana, M., Paruolo, P., \& Saltelli, A. (2017). Weights and importance in composite indicators: Closing the gap. Ecological Indicators, 80, 12-22. Doi: 10.1016/j.ecolind.2017.03.056.

Cadbury, S. A. (1992). Report of the committee on the financial aspects of corporate governance (1 ${ }^{\text {st }}$ ed.). London: Gee \& Co. Ltd.

Cressey, D. R. (1950, December). The criminal violation of financial trust. American Sociological Review, 15(6), 738-743. Doi: 10.2307/2086606.

DC Bar Pro Bono. (2015). Conflict of interest policies: Disclosure, montioring, and enforecement. Public Service Report, DC Bar. Retrieved December 2, 2018 from https:/ /www.probonopartner.org/wp-content/uploads/2016/08/dc-bar-alertconflict-of-interest-disclosure-10-15.pdf.

Eaton, T. V., \& Akers, M. D. (2007, June). Whistleblowing and good governance. The CPA Journal, 77(6), 66-71.

Elliott, A., \& Woodward, W. (2007). Statistical analysis quick reference guidebook with SPSS examples ( $1^{\text {st }}$ ed.). London: Sage Publications.

Fox, J. (2008, February 23). Conflict of interest policies: Not just more nonprofit documents. Retrieved January 23, 2019 from https://nonprofitquarterly.org/ 2018/02/23/conflict-interest-policies-not-just-nonprofit-documents /.

George, D., \& Mallery, P. (2016). SPSS for Windows step by step: A simple guide and reference, 11.0 update (14th ed.). Boston, MA: Allyn \& Bacon.

Ghafran, C., \& O'Sullivan, N. (2013, October). The governance role of audit committees: Reviewing a decade of evidence. International Journal of Management Review, 15(4), 381-407. Doi: 10.1111/j.1468-2370.2012.00347.x.

Ghasemi, A. \& Zahediasl, S.(2012). Normality tests for statistical analysis: A guide for non-statisticians. International Journal of Endocrinology \& Metabolism, 10(2), 486-489.

Harris, E., Petrovits, C. M., \& Yetman, M. H. (2015, March). The effect of nonprofit governance on donations: Evidence from the revised form 990. The Accounting Review, 90(2), 579-610. Doi: 10.2308/accr-50874.

Klemash, S., \& Lee, J.(2018, December 2). 2018 year-end issues for audit committees. Retrieved February 3, 2019 from https://corpgov.law.harvard.edu/ 2018/12/02/2018-year-end-issues-for-audit-committees/.

Krzeminska, A., \& Zeyen, A. (2016, April). A stewardship cost perspective on the governance of delegation relationships: The case of social franchising. Nonprofit \& Voluntary Sector Quarterly, 46(1), 71-91. Doi: 10.1177/0899764016643610.

Lampkin, L. M. (2008). Principles from the panel on the nonprofit sector: Yet another list of "shoulds"? Retrieved February 3, 2019 from https://www.guidestar.org/ Articles.aspx?path=/rxa/news/articles/2008/principles-from-the-panel-on-thenonprofit-sector.aspx.

Lee, P. C. (2015, June). Problems of implementing audit committee and supervisory board simultaneously in China. Journal of Accounting, Auditing \& Finance, 30(4), 509-528. Doi: 10.1177/ 0148558X15587649. 
Lee, T. A. (2001). A crisis of confidence: US auditing in the $21^{\text {st }}$ century. International Journal of Auditing, 5(1), 1-2. Doi: 10.1111/1099-1123.00321.

McDonnell, D., \& Rutherford, A. C. (2018). The determinants of charity misconduct. Nomprofit \& Voluntary Sector Quarterly, 47(1), 107-125. Doi: $10.1177 / 0899764017728367$.

Narayanaswamy, R., Raghunandan, K., \& Rama, D. V. (2015, April 27). Satyam failure and changes in Indian audit committees. Journal of Accounting, Auditing \& Finance, 30(4), 529-540. Doi: 10.1177/0148558X15584124.

National Council of Nonprofits. (2018). Board's role \& audit committees. Retrieved April 11, 2019 from https://www.councilofnonprofits.org/nonprofit-auditguide/board-role-audit-committee.

Nau, R. (2018). What's a good value for R-squared? Retrieved March 10, 2019 from https://people.duke.edu/ rnau/rsquared.htm\#top.

Pallant, J., (2007). SPSS survival manual, a step by step guide to data analysis using SPSS for windows ( $3^{\text {rd }}$ ed.). Sydney: McGraw Hill.

Puri, R., Trehan, R., \& Kakkar, H. (2010, January \& April). Corporate governance through audit committee: A study of the Indian corporate sector. The IUP Journal of Corporate Governance, $9(1 \& 2), 47-56$.

Saibaba, M. D., \& Ansari, V. A. (2012, May). Audit committees and corporate governance: A study of select companies listed in the Indian bourses. The IUP Journal of Accounting Research \& Audit Practices, 10(3), 46-54.

Shleifer, A., \& Vishny, R. W. (1997, June). A survey of corporate governance. The Journal of Finance, 52(2), 737-783. Doi: 10.1111/j.1540-6261.1997.tb04820.x

Sommer, A. (1991). Auditing audit committees: An educational opportunity for auditors. Accounting Horizons, 5(2), 19-93.

Song, M.-K., Lin, F.-C., Ward, S. E., \& Fine, J. P. (2013, January-February). Composite variables: When and how. Nursing Research, 62(1), 45-49. Doi: 10.1097/NNR.0b013e3182741948.

Templeton, G. F. (2011, January). A two-step approach for transforming continuous variables to normal: Implications and recommendations for IS research. Communications of the Association for Information Systems, 28(1), 41-58. Doi: 10.17705/1CAIS.02804.

The Panel on the Nonprofit Sector. (2007, October 1). Principles for good governance and ethical practice: A guide for charities and foundations. Washington, DC: Independent Sector.

The Washington Post. (2013). Millions missing, little explanation. Retrieved October 10, 2018 from http://www.washingtonpost.com/wp-srv/special/local/nonprofitdiversions-database/.

Todd, K. J. (2016, October 28). Why corruption always requires a conflict of interest. Retrieved October 10, 2018 from https://www.forensicstrategic.com/blog/whycorruption-always-requires-a-conflict-of-interest.

Turley, S., \& Zaman, M. (2004, September). The corporate governance effects of audit committees. Journal of Management \& Governance, 8, 305-332. Doi: 10.1007/s10997-004-1110-5.

UCLA Stats. (2016). Poisson regression: SPSS annotated output. Retrieved February 10, 2019 from https://stats.idre.ucla.edu/spss/output/poisson-regression/.

UCLA Stats. (2019). What does Cronbach's alpha mean? SPSS FAQ. Retrieved February 10, 2019 from https://stats.idre.ucla.edu/spss/faq/what-does-cronbachs-alphamean/. 